General information

\section{FEDERAL DISASTER ASSISTANCE IN THE UNITED STATES OF AMERICA}

In the United States of America, when natural disasters occur, local authorities have the prime responsibility to take immediate steps to alleviate suffering and protect life and property. If additional help is needed State police and National Guardsmen may be sent into the area by the Governor of the State. Other state resources are committed as the situation demands. Federal establishments particularly military installations - located in or near the disaster area may provide immediate lifesaving assistance. When the combined efforts of local and state forces are insufficient to cope with the effects of the disaster, the State may obtain assistance from other Federal agencies having statutory responsibilities for disaster relief.

If the magnitude and severity of a natural disaster warrants assistance beyond that available under the statutory authorities of individual Federal agencies, the Governor may request the declaration of a "major disaster" by the President. While he may rely on State and local officials for information needed to support his request, only the Governor can originate the request, certify the need for assistance, and assure reasonable expenditure of state and local funds. Any Federal disaster assistance is a supplement to - not a substitute for - relief provided by the state and its political subdivisions. The Governor's request is addressed to the President and presented to the Director of the Office of Emergency Preparedness through the appropriate OEP Regional Director.

When the President declares a "major disaster" the Office of Emergency Preparedness acts immediately to provide Federal assistance in accordance with the terms of the declaration. An allocation of funds may be made by the President at the time of the declaration. However, if the nature of the disaster precludes rapid damage assessment, only an initial allocation of funds may be made, or the allocation may be delayed until cost estimates are sufficiently refined to provide a reasonable basis for allocation of funds. Upon the declaration of a "major disaster" the State and the Federal Government execute a Federal-State Disaster Assistance Agreement which prescribes the manner in which Federal aid is to be made available and used.

The authority is established by the Federal Disaster Act of 1950 and the Disaster Relief Act of 1966. Basic information is presented in a Federal Disaster Assistance Handbook for Government Officials and in various pamphlets designed to inform the public. The following material is copied verbatim photographically from one of the pamphlets and is reprinted in the Bulletin with the written permission of Mr G.A. Lincoln, the present Director of the Office of Emergency Preparedness, as that agency was renamed in November 1968 .

\section{A Pocket Guide to Disaster Help}

This pamphlet is designed to inform the public of the scope of federal response to disaster. The many aspects of federal assistance have been treated in detail in the Federal Disaster Relief Manual (often known as the Humphrey Report). Our publication attempts to catalogue in brief form the contributions of the agencies which are permitted to participate in disaster operations.

Simple descriptions of the types of assistance which a state, a community or an individual might receive under appropriate conditions are listed by agency. More detailed information must be sought from the agencies themsevies.

For quick reference, an index is included. A bibliography lists sources of precise, detailed information on particular programs.

Agencies with Disaster Assistance Responsibilities.

Department of Agriculture - Page 6 Department of Commerce - Page 12

Health, Education, and Welfare - Page 8

Department of the Interior - Page 9

Department of Labor - Page 16

Treasury Department - Page 13

Post Office Department Page 7

Federal Communications Commission - Page 16

General Services Administration - Page 13

Veterans Administration - Page 7

Federal Aviation Agency - Page 11

Housing and Urban Development - Page 12

Interstate Commerce Commission - Page 17

Office of Economic Opportunity - Page 16

Office of Emergency Planning - Page 4

Civil Service Commission - Page 11

American National Red Cross - Page 14

National Defense Executive Reserve - Page 5

Office of Civil Defense - Page 11

Army Corps of Engineers - Page 10

Army-Navy-Air Force - Page 10

Coast Guard - Page 13

Federal Power Commission - Page 17

Small Business Administration - Page 17

Federal Disaster Assistance

Prepared by

Office of Emergency Planning

Executive Office of the President

(Revised) January 1967 
Farris Bryan, Director.

Page I

\section{Quick Powerful Federal Response}

When disaster strikes, bringing havoc and over-whelming local resources, the federal government is capable of nearly instant response bringing into play powerful forces mobilized from a great many branches of government.

Navy Task Group to Flood Scene

Under forced draft, a Navy aircraft carrier and destroyer sailed to Eureka, California, in December, 1964, to provide a floating base for a fleet of Army, Navy, Marine Corps and Coast Guard helicopters which ferried rescuers and supplies to hundreds of floodmarooned communities for as long as two weeks.

\section{Hurricane Triggers Battle Plan}

In a more recent example, the U.S. Fourth Army moved one thousand men and 328 vehicles into New Orleans to help the Red Cross and other services house and feed 24,000 victims of 1965's Hurricane Betsy. In battle-like reaction, troops and equipment sped to the stricken city by ground convoy and Air Force lift from forts as far as 500 miles distant.

Page 2.

When State Calls For Help

On behalf of the President, the Director of the Office of Emergency Planning coordinates federal assistance. The primary responsibility to cope with a local calamity lies with the community and state. When a governor certifies that resources at his disposal have been employed and that additional help is needed, he can ask the President for federal aid.

Different Types of U.S. Aid

Many departments and agencies are permitted by law to play a role in disaster rescue, relief and reconstruction. Much assistance is provided under the Federal Disaster Act (Public Law 81-875) which is administered by the President's Office of Emergency Planning.

Following a Presidential major disaster declaration, the law permits funds to be provided to the state or its communities for repair of damaged facilities. Funds are channelled through the state government. Other agencies may provide help to individuals, rather than to communities.

No Two Disasters Are Alike

Therefore, the pattern of federal help to stricken communities and individuals will vary. In a calamity as severe as Alaska's 1964 earthquake, several scores of federal agencies might become involved. Disasters of lesser magnitude might require the services of only one or two agencies of the federal government.

Federal men, material and money are organized and ready to augment state and local efforts at rehabilitation and relief in the wake of nature's calamities.

\section{Office of Emergency Planning}

Trained disaster specialists based at eight federal centers throughout the nation move out at first warning to areas imperiled by disaster.

Their field assessments of damage, relayed through Regional Directors to WAshington, form the basis for presidential judgment, should the governor ask for federal help.

The Federal Disaster Act, Public Law $81-$ 875, enables states and local governments to receive supplemental federal assistance when the President declares a major disaster.

The President has delegated administration of the federal disaster assistance program to the Office of Emergency Planning. This includes the authority to coordinate and direct the disaster relief activities of all federal agencies, and to administer disaster relief funds made ávailable by Congressional appropriation to the President. The Disaster Relief Act of 1966, Public Law 89-769, underlined the office of Emergency Planning's role in planning and directing federal assistance activities.

In a disaster of major proportions, the office of Emergency Planning will make damage assessments through such agencies as the Corps of Engineers, Bureau of Public Roads, Public Health Service and Community Facilities Administration.

After the President declares a major disaster, the Office of Emergency Planning may direct any federal agency to provide assistance to:

Page 4

- Utilize or lend, with or without compensation to state and local government, equipment, supplies, facilities, personnel, and resources other than extension of credit under the authority of any Act.

- Distribute, through the American National Red Cross or otherwise, medicine, food and other consumable supplies.

- Donate or lend to states, for their use or distribution surplus equipment and supplies.

- Perform, on public or private lands, protective and other work to preserve life and property.

- Provide temporary housing or emergency shelter.

- Clear debris and wreckage, and make emergency repairs and temporary replacement of essential public facilities, such as roads, bridges, water and sewer systems, public buildings, of state and local governments.

The Office of Emergency Planning may render financial assistance to:

- State and local governments for work to protect life and property, to clear debris and wreckage, and to make emergency repairs to and temporary replacements of essential public facilities of state and local governments, includina provisions for temporary 
housing or emergency shelter.

- Federal agencies as reimbursement for disaster relief assistance directed by the Office of Emergency Planning.

Executive Reserve

The Office of Emergency Planning may activate members of the National Defense Executive Reserve to assist other federal officials in recovery and rehabilitation efforts.

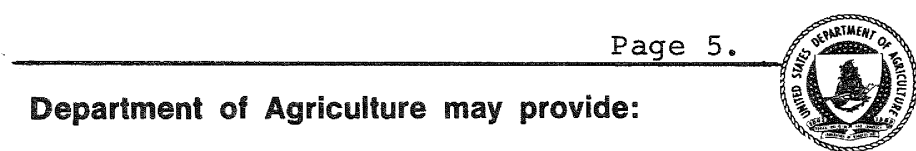

Credit to enable disaster stricken farmers to replace lost livestock and equipment and resume farming operations and to enable farmers and other rural residents to repair or replace damaged homes and farm buildings (Farmers Home Administration).

- Food stocks for emergency mass feeding by disaster relief agencies, and for direct distribution to needy persons through public welfare agencies (Consumer and Marketing Service).

- Assistance in obtaining reduced transportation rates for expediting movement of hay to disaster areas (Consumer and Marketing Service).

- Technical assistance and information in the areas of sanitation, feeding, and rehabilitation (Consumer and Marketing Service, and Extension Service).

Free Commodity Credit Corporation-owned feed grains to stranded or comingled livestock in the disaster area (Agricultural stabilization and Conservation Service).

- CCC-owned feed grains at reduced prices to help maintain eligible livestock herds in areas designated as disaster areas by the secretary of Agriculture (Agricultural Stabilization and Conservation Service).

- Use of Conservation Reserve, or feed grain and wheat lands taken out of crop production, for hay harvesting and grazing of livestock in areas designated as disaster areas by the Secretary of Agriculture (Agricultural Stabilization and Conservation Service).

\section{Page 6.}

\section{- Cost-sharing on emergency conservation} measures under the Agricultural Conservation Program to help farmers repair and restore farmlands and facilities damaged by natural disasters in designated areas (Agricultural Stabilization and Conservation Service).

- Technical assistance for restoration of flood-damaged agricultural land and restoration of farm levees, drainage ditches, irrigation canals, etc., and preparing estimates of damages (Soil Conservation Service).

Credit and technical assistance to REAfinanced electric and telephone systems which have suffered damage (Rural Electrification Administration).
- Indemnity payments to farmers on insured crops (Federal Crop Insurance Corporation).

- Assistance in control of rural fires in and near national forests (Forest Service).

\section{Post Office Department may provide:}

- Emergency locator information and materials. in cooperation with the Red Cross, for disaster evacuees.

Temporary emergency postal delivery sites, facilities and personnel to expedite delivery of priority mail until normal operation poss= ible in disaster areas.

\section{Veterans Administration may provide:}

- Loan adjustments and relief to assist veterans in the retention and repair of their property.

- Guarantee of new loans.

- Speedy processing of claims and allowances for veterans.

- VA medical facilities, equipment and personnel for emergency work.

\section{Page 7.}

Department of Health, Education and Welfare may provide:

Funds and personnel for disease control (Public Health Service).

- Assistance in maintaining sanitary conditions - sewage, water supply, etc. (Public Health Service).

- Emergency medical care (Public Health Service).

Hospital and clinical facilities including the activation of Packaged Disaster Hospitals or Emergency Medical Supply Depots (Public Health Service).

- Protection from contaminated foods and drugs (Food and Drug Administration).

- Assistance to state and local public welfare agencies to enable them to provide: financial and medical assistance to eligible needy persons; personnel trained in emergency welfare service; social services for families, including casework services and rehabilitation services such as work training, day care, foster family care, or care in institutions for children, services and care for aged persons, mentally retarded children, and other children and adults with special problems (Welfare Administration).

- Assistance to state vocational rehabilitation agencies to enable them to provide: rehabilitation facilities and services; restorative medical and surgical services; and job training and placement (Vocational Rehabilitation Administration).

- Emergency processing of claims for social 
security benefits (Social Security Administration).

- Financial assistance for: repair or restoration of damaged public school facilities; replacement of materials, supplies, and equipment; establishing and operating temporary schools pending repair or replacement of damaged facilities; maintenance and operation of schools damaged in a major disaster (Office of Education) .

Surplus real and personal property for health and educational purposes (Office of the secretary).

\section{Department of Interior may provide:}

- Personnel and equipment for mine safety and rescue operations. (Bureau of Mines).

Personnel and contract organization including flood control, generation and tranmission of hydro-electric power and domestic water supplies. Operates in the 18 Western States, including Alaska (Bureau of Reclamation).

- Personnel and equipment for fire fighting, snow removal and road repair on federal reservations (Bureau of Land Management).

- Trained personnel and information concerned with water resources; extensive maps (Geological Survey).

- Temporary lodging and food services, personnel and equipment for the maintenance and repair of roads, trails, buildings, and utilities (National Park Service).

- All effort for the care and assistance of Indians throughout the United States (Bureau of Indian Affairs).

Law enforcement, search and rescue personnel and equipment (Bureau of Sport Fisheries and Wildlife).

- Personnel trained in operating an electricpower-distribution organization. Provides trucks, radio-equipped cars, handtools, general supplies; operates in Oregon, Washington, northern Idaho, and western Montana (Bonneville Power Administration).

- Personnel trained in operating an electricpower-distribution organization. Trucks, radioequipped cars, handtools, general supplies; operates roughly within a 200-mile area surrounding Tulsa, Oklahoma (South-western Power Administration).

\section{Army-Navy-Air Force}

Page 9.

The Department of the Army is responsible for the control of Defense Department domestic emergency operations and for coordinating the participation of the Air Force and Navy.

Military assistance may be provided when state and local resources are clearly inadequate and immediate action is required to prevent starvation, extreme suffering and loss of life and property. The military may assist in rescue, evacuation, and provision of shelter, food and medical care. Assistance by the military is provided as the situation warrants, and may consist of personnel or the use of facilities, equipment and supplies.

\section{Army Corps of Engineers may provide:}

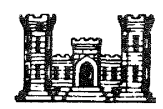

Flood fighting and flood control activities including repair and reconstruction of flood control works.

Repair and restoration of federally-constructed hurricane or shore protective works.

Protective and other immediately required health and safety measures.

Debris clearance, sanitation services or the emergency repair or replacement of public facilities performed by direction of the office of Emergency Planning.

\section{Office of Civil Defense may provide:}

Assistance to state and local officials in their preparations to meet disaster emergencies The programs of OCD although directed toward meeting the effects of enemy attack have direct application in natural disaster emergencies. Assistance in planning and preparing for emergency includes technical and operational guidance, training and education, and financial assistance for establishment of adequate systems for warning, communications, emergency operating centers, and full-time professional staffs.

Skilled disaster personnel for liaison with and emergency assistance to state and local governments. Trained specialists in warning, communications, engineering, radiation defense, public information and general emergency operations are assigned to each OCD regional office and are readily available as consultants.

Use of stockpile civil defense equipment and supplies such as pipe, pumps, generators and shelter supplies. Additionally, civil defense equipment obtained by state and local governments through federal matching funds or donation may be used.

\section{Civil Service Commission may provide:}

Personnel and equipment to assist federal and/or local governments in disaster relief activities.

\section{Federal Aviation Agency may provide:}

- Use or loan of available aircraft for transportation of supplies and equipment.

Technical assistance for damage assessments to public airports.

Page 11 .

Department of Housing \& Urban Development may provide:

Interest free advances for rehabilitation 
planning: loans at reasonable interest rates for construction of public facilities (Community Facilities Administration).

- Requirements waived in rendering financial assistance to urban areas in need of redevelopment or rehabilitation as a result of major disaster (Urban Renewal Administration).

Loan adjustments on FHA assured loans; temporary housing for disaster victims in defaulted FHA-insured homes; Rent supplement payments to occupants of dwellings damaged or destroyed by disaster subsequent to April 1. 1965. To be eligible, tenant's income cannot exceed maximum amount Federal law permits to be established in area for occupancy of Federally-aided, low-rent public housing. (Federal Housing Administration).

Special mortgage purchasing and commitment authorities on FHA-insured or VA guaranteed loans (Federal National Mortgage Association).

- Temporary housing for disaster victims in available public housing (Public Housing Administration).

\section{Department of Commerce may provide:}

Reconstruction of federal-aid highways and bridges (Bureau of Public Roads).

- Priority assistance, including loan of equipment to industries with defense contracts (Business and Defense Services Administration).

- Weather forecasts and storm warnings, flood warnings, and forecasts of water levels (U.S. Weather Bureau - Environmental Science Services Administration).

- Assistance in coordinating transportation intelligence and service available (Office of Emergency Transportation).

- Seismic Seawave Warnings (Tsunami or Tidal Wave) with international participation including Japan, Canada, Chile, Formosa, and the Philippines (Coast and Geodetic Survey Environmental Science Services Administration)

Page 12.

\section{General Services Administration may provide:}

- Transportation or communications services to state and local agencies (Transportation and Communications Service).

- Engineering and architectural services; office and shelter space in disaster areas (Public Building Service).

- Use of excess and surplus properties for disaster relief purposes (Utilization and Disposal Services).

- Emergency procurement and warehousing operations in disaster areas (Federal supply Services).

- Lease of idle government-owned tools and production equipment; sale of excess materials from national stockpile and other agencies (Defense Materials Service).

\section{Department of the Treasury may provide:}

- Arrangement for release and procurement of medical narcotics needed in an emergency.

Income and other tax relief of many types for disaster victims (Internal Revenue Service).

U.S. Coast Guard may provide:

- Search, rescue and evacuation of disaster victims, transportation of supplies and equipment; emergency communications; emergency marking of waterways (U.S. Coast Guard).

Page 13.

\section{American National Red Cross}

The Red Cross, a voluntary organization chartered by the Congress, acts in close cooperation with federal agencies. All assistance given by Red Cross to disaster victims is on the basis of outright grants - no loans are made and there is no obligation for repayment.

Relief assistance includes:

- Assisting government in disseminating warnings of approaching or impending catastrophes.

- Transport and storage of household furnishings for voluntary evacuation of affected persons and their belongings.

- Mobilize volunteers to assist government in rescue operations.

- Provide emergency information concerning welfare of evacuees and those in path of disaster.

Mass care for disaster victims which includes:

- Food at fixed and mobile feeding stations.

- Clothing by utilizing donated articles or securing by local purchase for distribution.

- Shelter in temporary centers or placement in homes or multi-dwelling facilities.

Medical and nursing care in cooperation with and assistance of public health offices, physicians, dentists, nurses, and hospitals by providing additional facilities to meet the emergency. This care may include:

- Arranging for transportation for injured and sick.

- Provision of additional physicians and nurses to supplement local hospital staffs.

- Arrangement of hospital care for disaster victims.

Page 14.

- Establishment of emergency aid stations.

- Furnish medical and hospital supplies.

- Provision of medical and nursing care in shelters. 
- Assign nurses for bedside care in hospitals and homes.

Rehabilitation and recovery assistance designed to bridge the gap between what the family is able to accomplish for itself, and what it actually needs to resume normal family life in the home and community. Disastercaused need and not loss is the basis upon which assistance is afforded.

Following an evaluation of needs and resources available, assistance may be provided to include the following:

Food, clothing, and other maintenance, until the family income is restored or other regularly constituted benefits are obtainable in the community.

- Repair or rebuilding of owner-occupied homes and other essential structures.

Household furnishings. Purchase of basic furnishings essential to family living.

Medical and nursing care for those made ill or injured because of the disaster, or whose condition is aggravated by the disaster.

Occupational supplies and equipment for small farmers, owners of small businesses, and self-employed individuals and families in need of occupational equipment.

Trained personnel for:

- Administration and supervision of disaster relief operations.

- Survey of disaster damage.

- Nursing care.

Page 15.

\section{American National Red Cross (continued)}

- Advice as to repair or replacement of damaged housing.

- Disaster casework.

Financial:

- Grants of funds for emergency care and individual family rehabilitation assistance.

\section{Department of Labor may provide:}

- Special emergency sub-offices of the state employment security agency to better serve workers in need.

- Recruitment of workers for cleanup and rehabilitation operations.

- Manpower from Neighborhood Youth Corps units.

Federal Communications Commission may provide:

Priority assignment to radio communications systems engaged in emergency work.

Temporary authorization to radio and television stations for use in emergency

situations.

- Frequency allocation to amateur operators for emergency relief messages.

Office of Economic Opportunity

The Job Corps and the Neighborhood Youth Corps may provide:

- Manpower for debris clearance, flood protection, rehabilitative projects, subject to the governor's approval.

Page 16.

\section{Small Business Administration may provide:}

- Long-term, low-interest loans to individuals, home-owners, businesses, and nonprofit organizations such as churches. Loans may be used for real estate repair and replacement and repair and replacement of furnishing equipment, fixtures, and inventory.

- Long-term, low-interest loans to small businesses which are located in areas of major or natural disaster as determined by the President or Secretary of Agriculture, and which have suffered substantial economic injury from the disaster.

Interstate Commerce Commission may provide:

- Increased transportation services to disaster areas by granting temporary authority to carriers and by waiving restrictive regulations.

- Traffic priorities for affected areas rail, water or highway.

- Permission for common carriers to transport passengers without charge, or freight at reduced rates, into or out of disaster areas.

\section{Federal Power Commission may provide:}

- Authority to order interconnection of electrical facilities and emergency support in disaster situation.

Page 17.

\section{Federal Assistance Index}

Problem or Service Desired Agency to Consult

Communications

Conservation, Farm

Contaminated Food-

Drugs

Crop Insurance

Damage Assessments

Debris Clearance

Disaster Plans

Disease Control Employment Assistance Executive Reserve
Federal Communications Commission.

Agricultural Stabilization \& Conservation Food \& Drug Administration

Federal Crop Insurance Corporation

Office of Emergency Planning

Office of Emergency Planning Office of Emergency Planning, Office of Civil Defense Public Health Service Department of Labor Office of Emergency Planning. 


\section{Problem or Service Desired Agency to Consult}

Family \& Individual -

food, clothing, shel-

ter, household furn-

ishings, repairs and American National Red

financial assistance

Federal Agency

Coordination

Feed Grains - Reduced

Prices

Flood Fighting

Flood Protection

Free Feed Grains

Haying \& Grazing

Home Loan Adjustments

Loans, Community

Facilities

Cross

Office of Emergency

Planning

Agricultural Stabiliza-

tion \& Conservation

U.S. Corps of Engineers

U.S. Corps of Engineers,

Bureau of Reclamation

Agricultural Stabiliza-

tion \& Conservation

Agricultural Stabiliza-

tion \& Conservation

Federal Housing Administration; Veterans Administration

Community Facilities

Administration

Loans, Economic injury Small Business Administration

Loans, Farming

Operation

Loans, Homes-Business

Loans, Rural Housing

Locator Service

Mail Service

Manpower

Maps

Medical Care

Military Assistance

Military Coordination

Farmers Home Administration

Small Business Administration

Farmers Home Administration

Post Office Department: American National Red Cross

Post Office Department

Office of Economic

Opportunity; Department of Labor

Coast \& Geodetic Survey;

Geological Survey

Public Health Service;

American National Red

Cross

Department of Defense

Department of the Army

\section{Page 18}

Repair Federal Air

Roads

Reduced Transportation Interstate Commerce

Rates

Rehabilitation,

Vocation

Repair - Public

Facilities - roads,

bridges, sewer \& water Office of Emergency

systems, public

buildings \& facilities

Repairs - shore \&

hurricance protec-

tive works

Repairs - Roads,

streets, \& bridges

Sanitation

Schools, Maintenance

\& Operation

Schools, Repair

Search \& Rescue

Social Security

Benefits

Soil Restoration

Stockpile Civil

Defense Equipment

Surplus Foods
Bureau of Public Roads

Commission

Vocational Rehabilita-

tion Administration

Planning

U.S. Corps of Engineers

Office of Emergency

Planning

Public Health Service

Office of Education

Office of Education

Coast Guard

Social Security

Administration

Soil Conservation

Service

Office of Civil Defense

Consumer \& Marketing

Service

Problem or Service Desired Agency to Consult

Surplus Property

Tax Assistance

Temporary HousingShelter

Tidal Wave Warning

Transportation

Urban Renewal

Veterans Benefits

Weather Warning

Welfare Aids
Warehousing

Department of Health, Education and Welfare; Office of Civil Defense; Office of Emergency Planning; General Services Administration Internal Revenue Service Office of Emergency Planning; American National Red Cross Coast and Geodetic Survey

Interstate Commerce

Commission; General

Services Administration; Federal Aviation Agency

Urban Renewal Administration

Veterans Administration

General Services

Administration

U.S. Weather Bureau

Welfare Administration

Page 19

\section{Bibliography}

American National Red Cross. In the Wake of Disaster. Rev. ed. Wash., Feb. $19636 \mathrm{p}$. (ARC 969)

- Information for Disaster Victims. Rev. ed. Wash., Jan. 1963 2p. (ARC 1578)

- Your Community Could have a Disaster. Rev. ed. Wash., Nov: 1959 3p. (ARC 1570)

U.S. Corps of Engineers. Disaster Activities of the Corps of Engineers. Wash., Dept. of the Army, Office of the Chief of Engineers Sep. 21, 1964.

-- Emergency Flood Control and Shore Protection Activities of the Corps of Engineers. Wash.. Dept. of the Army, Office of the Chief of Engineers, Sept. 15, 1964.

U.S. Dept. of Agriculture. First Aid for Flooded Homes and Farms. Wash., Govt. Print. Off., Nov. 1964 28p. (Agriculture Handbook \#38) $15 \%$

-- U.S. Department of Agriculture's Donated Foods for Disasters, a Guide for State and Local Officials. Wash., Govt. Print. Off., Apr. 1963 5p. (PA-557)

- What the U.S. Department of Agriculture Can Do When Natural Disaster Strikes, Govt. Print. Off., Jan. 1963 7p. (PA-533)

U.S. Dept. of Commerce. Bur. of Public Roads. Federal Assistance Available When a Natural Disaster Damages Roads, Streets and Bridges. Wash., $196318 \mathrm{p}$.

-- Weather Bureau. Tornadoes. Wash., Govt.Print. Off. Apr. 1965 13p. 20\$; $\$ 15$ per hundred.

U.S. Executive office of the President. Off. of Emergency Planning. Federal Disaster Assistance Handbook for Local Government officials. Wash., Govt. Print. Off., 1965. 16p. (OEP Circular 4000.3B) 
- Hurricane Betsy: Federal Action in Disaster. Wash., Govt. Print. Off., 1966. 30 p.

- Instructions to Applicants Natural Disaster Program. Wash., May 1965 43p. (OEP Circular $4000.5 \mathrm{~A}$ )

- Natural Disaster Manual for State and Local Applicants, incl. Appendix. Wash., Govt. Print. Off., $196388,22 \mathrm{p}$. (OEP Circular 4000.4)

U.S. Federal Communications Commission. Commission Will Consider Requests for Waiver of Filing Fees for Modification Applications Occasioned by Natural Disasters. Wash., July 22 , 1965 Ip. (Public Notice G, FCC 65-669: 70505)

U.S. Housing and Home Finance Agency. Natural Disaster Aids: Information on Natural Disaster Aids Available Through Housing and Home Finance Agency. Washington, Jan. $19657 \mathrm{p}$.

Page 20 .

U.S. Public Health Service. Austere Medical Care for Disaster: a Reference Manual for Allied Workers and Selected Trained Laymen. Wash., Govt. Print. Off., 1964 73p. (Health Mobilization Series D.1. PHS Publication No. 1071-D-1)

- Community Emergency Health Manpower Planning. Rev. ed. Wash., Govt. Print. Off.. 1964 20p. (Health Mobilization Series 1-1. PHS Publication No. 1071-1-1)

-- Community Emergency Health Preparedness. Wash., Govt. Print. Off., 1964 20p. (Health Mobilization Series A-2 PHS Publication No. $1071-A-2) 15$ c

- Emergency Health Service Preparedness Check List. Wash., Govt. Print. Off., $19654 \mathrm{p}$ (Health Mobilization Series A-3. PHS Publication No. $1071-\mathrm{A}-3$ )

-- Establishing the Packaged Disaster Hospital. Rev. ed. Wash., Govt. Print. Off., Dec. 1964 40p. (Health Mobilization Series F-1. PHS Publication No. 1071-F-1) 20 c

- Illustrated Catalog and Guide for Distribution of Packaged Disaster Hospital Materials Wash., Govt. Print. Off., Sept. 1965 178p. (Health Mobilization Series F-15. PHS Publication No. 1071-F-15) \$1.25

-- Packaged Disaster Hospitals. Wash. , Govt. Print. Off., 1965 5p. (PHS Publication No. 1311)

-- Theropeutic Guide for Pharmaceuticals in the Packaged Disaster Hospital. Wash., Govt. Print. Off., 1965. 142p. (Health Mobilization series C-1. PHS Publication No. $1071 \mathrm{C}-1) 55 \mathrm{f}$

U.S. Public Health Service and Dept.of Defense Office of Civil Defense. If Disaster Strikes and There Is No Doctor: Medical Self-help for You and Your Community. Rev. ed. Wash. , Govt. Print. Off., June 1965. 32p. (PHS Publication No. 1042)

U.S. Smal1 Business Administration. Economic Injury Disaster Loans: Management and Technical Aid for Displaced Small Businesses.
Wash., Govt. Print. Off., April 1965. 5p. $(\mathrm{OPI}-4)$

-- Economic Injury Disaster Loans for Small Firms, Natural Disasters. Wash., Govt. Print. Off., Nov. 1964. 5p (OPI-1)

-- Economic Injury Disaster Loans for Small Firms, Product Disasters. Wash., Govt. Print. Off., Nov. 1964. 5p. (OPI-3)

-- Economic Injury Disaster Loans for Small Firms, Storms and other Major Disasters. Wash, Govt. Print. Off., Nov. 1964. 5p. (OPI-2)

- Smal1 Business Administration Disaster Loans to Restore or Replace Businesses, Homes. Wash, Govt. Print. Off., Oct. 1964. 10p. (OPI-9)

U.S. Treasury Department. Internal Revenue Service. Disasters, Casualties and Thefts How the Federal Income Tax Applies. (Document No. 5174-12/64). Wash., Govt. Print. Off., 1965. 20p.

U.S. Congress, 88th, First Session, Senate Committee on Government Operations Federal Disaster Relief Manual, Rev. ed. Wash., Govt. Print. Off. Aug. 30, 1963. 150p. (Committee print). 50\%

Page 21.

The Eight Regional Directors of The Office of Emergency Planning Will Provide Addresses of The Closest Federal office With Relief Responsibilities;

Region 1 - Albert D. O'Connor, Regional Director, Office of Emergency Planning; George A. Flowers, Regional Disaster Coordinator; Oak Hill Road, Harvard, Mass. 01451

Phone: 617-GI 6-3231

(Connecticut, Maine, Massachusetts, New Hampshire, Vermont, Rhode Island, New Jersey, New York, Puerto Rico, and the Virgin Islands.

Region 2 - Robert J. Carmody, Regional Director, Office of Emergency Planning: Olney. Maryland 20832

Phone: 301-921-5512

(Delaware, District of Columbia, Kentucky, Maryland, Ohio, Pennsylvania, Virginia, and west Virginia.)

Region 3 - Earl E. Mader, Regional Director, Office of Emergency Planning; Ronard B. VanDame, Regional Disaster Coordinator: P.O. Box 108, Thomasville, Georgia 31792 Phone: 912-226-1761 (Alabama, Florida, Georgia, Mississippi, North Carolina, South Carolina, and Tennessee.)

Region 4 - Frank P. Bourgin, Regional Director, Office of Emergency Planning; Leo C. McNamee, Regional Disaster Coordinator-Federal Center, Battle Creek, Mich. 49016

Phone: 616-968-8142

(Illinois, Indiana, Michigan, Minnesota and Wisconsin.) 
Region 5 - George E. Hastings, Regional Director, Office of Emergency Planning; Walter C. Ilgenfritz, Regional Disaster Coordinator: Denton Federal Center, Denton, Tex. 76204 Phone: 817-387-5811

(Arkansas, Louisiana, New Mexico, Oklahoma, and Texas.)

Region 6 - Donald G. Eddy, Regional Director, Office of Emergency Planning; Kent M. Hutton, Regional Disaster Coordinator: Denver Federal Center, Building 50, Denver, Colorado 80225 - Phone: 303-233-3611

(Colorado, Iowa, Kansas, Missouri. Nebraska, North Dakota, South Dakota and Wyoming.)

Region 7 - George M. Grace, Regional Director, Office of Emergency Planning; Ralph D. Burns, Regional Disaster Coordinator: Santa Rosa, California 95401

Phone: 707-544-1330

(Arizona, California, Hawaii, Nevada, Utah, American Samoa, Guam and Trust Territory of the Pacific Islands.)

Region 8 - Creath A. Tooley, Regional Director, Office of Emergency Planning; Raymond E. Willman, Regional Disaster Coordinator: Everett, Washington 96201

Phone: 206-AL 9-7191

(Alaska, Idaho, Montana, Oregon and Washington.)

\section{Announcement-THIRD JAPAN \\ EARTHQUAKE ENGINEERING}

\section{SYMPOSIUM 1970}

The Third Japan Earthquake Engineering Symposium - 1970 is scheduled to be held in Tokyo in November of this year under the joint auspices of the Architectural Institute of Japan, Japan Society of Civil Engineers, the Japanese Society of Soil Mechanics and Foundation Engineering, and Seismological Society of Japan, in accordance with the established precedent that it has been held in an intermediate year between the meetings of the World Conference on Earthquake Engineering; the first Symposium was held in 1962 and the second in 1966, both in Tokyo.

The Japan Earthquake Engineering Symposium has acquired a deep significance as a research meeting covering extensive fields of interest and its Proceedings have been highly rated as of the highest level in this field of engineering.

As well as Japanese specialists, foreign engineers and scientists interested in the fields of engineering seismology, earthquake engineering, and related matters are cordially invited to actively participate in, and to present technical papers to, the forthcoming Symposium.

\section{Tentative Program}

i) Date: November 17 (Tues) through 20 (Fri) 1970 .

ii) Place: Halls at the Daiichi-Seimei Co. and the Tokyo Chamber of Commerce $\&$ Industry

iii) Subjects:Oral presentation of papers, panel discussions, and tour

iv) Subject of Panel discussions: Ground Behaviour during Earthquakes, and Interaction between the Ground and Structures

v) Tour: Inspection of a Large-Size Shaking Table, National Research Center for Disaster Prevention, Science and Technology Agency, at Tsukuba, Ibaragi Pref.

\section{Technical Papers}

i) Content

The presentation of research papers on earthquake engineering and related matters are invited. Papers may contain materials previously published, but those containing new developments will be welcomed.

ii) Preliminary application

a) It is requested that an abstract of less than 400 words in English for each complete paper be sent to the following address not later than May 15, 1970: Organizing Committee

Japan Earthquake Engineering Symposium1970

C/- Japanese Society of Soil Mechanics and Foundation Engineering

Toa-Bekkan, 13-5, 1-chrome, Nishishinbashi, Minato-ku

Tokyo, Japan.

In the abstract, the name, affiliation, position, and mailing address of each author should be described.

b) A paper or two papers per author can be accepted including the case of co-authorship. As a rule, however, the oral presentation will be limited to one per participant; therefore, in the case of co-authorship. the speaker should clearly be specified.

c) The Organizing Committee will decide the acceptance of papers based on review of the abstracts, and will notify the authors of the acceptance as quickly as possible.

d) The authors of the accepted papers must airmail the completed papers to reach the Organizing Committee by the end of July, 1970. They are also requested to remit the publication fee of 10 U.S. Dollars per paper to the Organizing Committee to assist the finances of the Symposium.

e) Detailed instructions for the presentation of completed papers will be informed later to the authors of the accepted papers. The completed paper should be typewritten in English and its maximum length will be 8 pages (approximately, 4000 words). Proceedings are to be reproduced directly from the original copy of the author's typescript and will be available at the opening of the Symposium. Discussions during the Symposium will be published afterwards and distributed as appendix to the Proceedings. 